\title{
INFORMATION SUPPORT MODEL AND ITS IMPACT ON UTILITY, SATISFACTION AND LOYALTY OF USERS
}

\author{
Sead Šadić ${ }^{1, *}$, Adis Puška ${ }^{2}$, Admir Beganović ${ }^{3}$ \\ ${ }^{1}$ Government of Brčko District B\&H, \\ Bulevar mira 1, Brčko, Bosnia and Herzegovina \\ ${ }^{2}$ College of Computer Science and Business Communications eMPIRICA, \\ Bulevar mira 10, Brčko, Bosnia and Herzegovina \\ ${ }^{3}$ The University of Business Studies \\ Jovana Dučića 23a, Banja Luka, Bosnia and Herzegovina
}

\begin{abstract}
:
In today's modern age, information systems are of vital importance for successful performance of any organization. The most important role of any information system is its information support. This paper develops an information support model and presents the results of the survey examining the effects of such model. The survey was performed among the employees of Brčko Distric Government and comprised three phases.

The first phase assesses the influence of the quality of information support and information on information support when making decisions. The second phase examines the impact of information support when making decisions on the perceived availability and user satisfaction with information support. The third phase examines the effects of perceived usefulness as well as information support satisfaction on user loyalty. The model is presented using six hypotheses, which were tested by means of a multivariate regression analysis.

The demonstrated model shows that the quality of information support and information is of vital importance in the decision-making process. The perceived usefulness and customer satisfaction are of vital importance for continuous usage of information support. The model is universal, and if slightly modified, it can be used in any sphere of life where satisfaction is measured for clients and users of some service.

\section{Key words:}

information system, information support, information support model, satisfaction, loyalty.
\end{abstract}

\section{INTRODUCTION}

Information technologies play an important role in modern business. The rapid growth of the Internet as communication media represents the crucial element of support and success in everyday business. The information technology develop- ment did not bypass the public sector. Information technology is nowadays seen as a mechanism for business advancement and improvement. The most important section of information system is information support itself. The use of information support in public sector contributes to making everyday decisions, resolution of business pro- 
cesses and enables efficient communication and all other processes up to final data archiving.

Information system eases the accomplishment of everyday activities and all other requests. It should enable the user to obtain quick and adequate information. Today's decision makers are faced with the problem of excessive information. In the decision-making process, it is necessary to receive useful information at the right moment with it being complete and consistent. Information in today's business environment is the most valid resource that facilitates the decision-making process and decreases the level of uncertainty and risk.

The following research topic arises from the present research: how does the organization of local government enhance its functioning by introducing information technologies. The other topic refers to the way in which the information support quality affects the decision making process with regards to the perceived client utility, satisfaction and loyalty.

In order to examine the research subject, it is necessary to examine the impact of information system quality and information in general on information support when making decisions and its influence on the perceived usage and satisfaction of information support, which further results in information support system loyalty.

To that end, it is necessary to set up an information support model and determine the indicators used to measure the research varieties. In order to prove this research model, multi-variation regression analysis shall be utilized.

\section{THEORETICAL FRAMEWORK OF RESEARCH MODEL}

Modern efficient business decision making cannot be imagined without information systems. Information systems and technologies are used as support to all aspects of organizational functions and activities (Marković Blagojević et al. 2014, p.
34). The task of information systems is to provide adequate information support to the user/client. In order to make the right decision, every manager is required to have "the real database of information for decision making and determining each type of information needed to make the proper decision" (Mahmutović et al., 2012, p. 42). Therefore, it is required that each information system user knows how to obtain the required information in order to make a decision and resolve the problem. Information systems should provide information support based on which decisions will be made and everyday activities successfully performed.

The use of information systems results in adequate information support provided to the client/user. Therefore, this paper will observe how information systems used in Brcko District Government affect the decision-making process and problem solving and whether the users would continue to use them, i.e. remain loyal. The paper develops the model that will serve as the basis for this research.

The following assumptions were taken into consideration when creating the research model:

- information support quality is important for the decision-making process,

- quality of information obtained from information systems is important for the decision- making process,

- decision-making process is connected with usage perception and client satisfaction by using information support,

- Information support perceived level of usage and satisfaction determines the loyalty level and readiness for continuation of service usage.

The given assumptions indicate three relations based on which the following varieties would be used:

- quality of information support on decision making

- efficiency and satisfaction and

- efficiency and satisfaction on loyalty. 


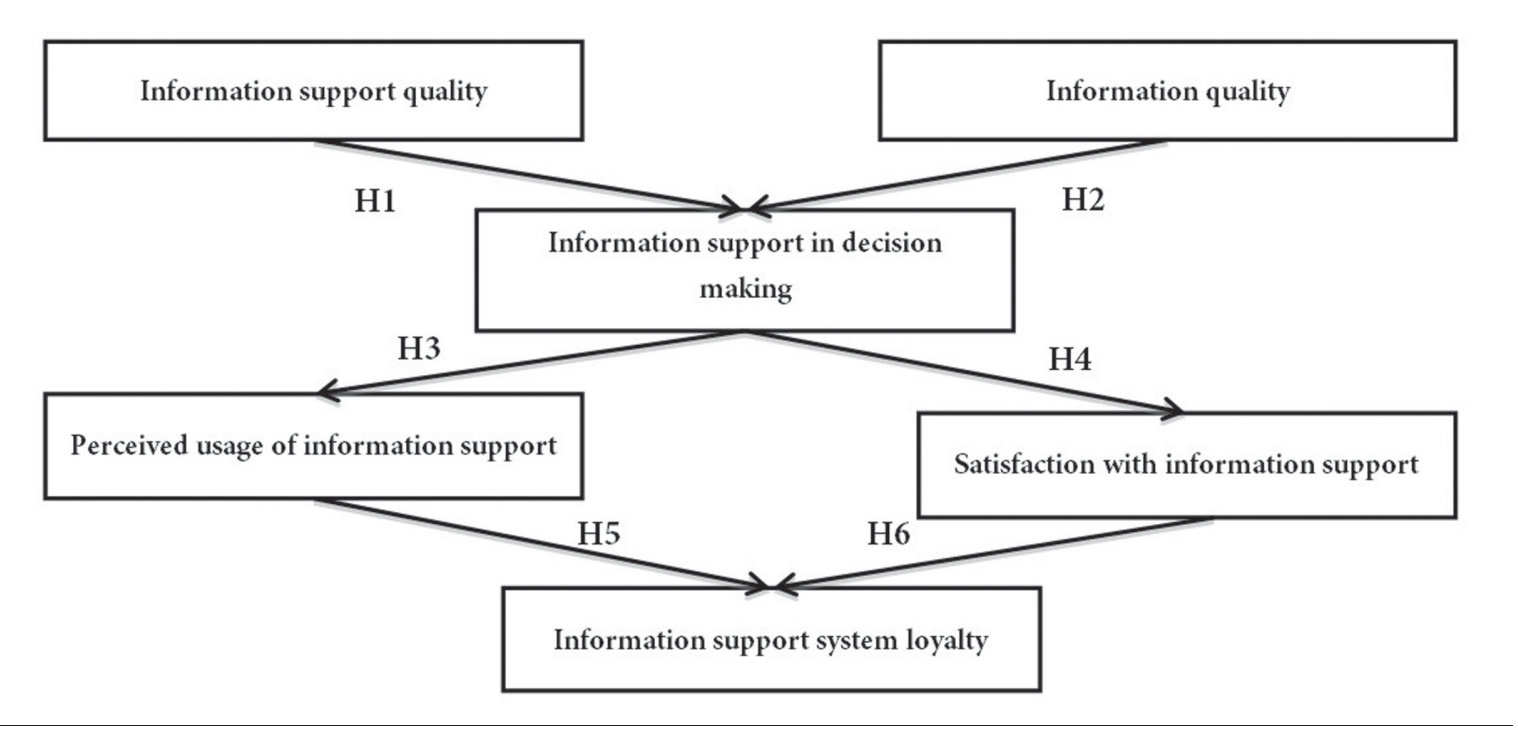

Image 1. Research model

The first relation sees the information support quality and quality of information obtained by using information support as independent varieties. In the first relation, information support in the decision-making process is seen as a dependent variety. The second model relation sees information support in the decision-making process as an independent variety, whereas the perceived efficiency of information support and satisfaction with information support is seen as a dependent variety. The third model relation has the perceived efficiency of information support and satisfaction with information support as independent varieties, whereas the loyalty of information system support is marked as a dependent variable.

Based on this research model, the following hypotheses are established:

H1 - Information support quality influences decision making in everyday business activities of the user,

H2 - Information quality influences decision making in everyday business activities of the user,

H3 - Information support in the decision making influences the user's perceived efficiency of this support,

H4 - Information support in decision making influences the user's satisfaction with this support,
H5 - There is a significant influence of the perceived efficiency on loyalty when using the information support system,

H6 - There is a significant influence of satisfaction on loyalty when using the information support system.

\section{INFORMATION SUPPORT QUALITY}

Quality is a multidimensional term which can be observed from various aspects. The term quality will be used to show its conveniences for usage, considering that the information system users have different needs, requests, wishes, and diverse interpretations of its quality Petter et al. (2008, pp. 238-239). The users define quality of information system through its desired characteristics such as intuitiveness, sophistication, flexibility and response time.

The aim of the information system is to be simple for usage by providing information support. It needs to be in compliance with the requirements and client wishes.

Information needs to be accessible quickly at all times. "High quality of information system management means high information quality through efficiency and satisfaction or decision maker and increases the manager's decision quality" (Al-Mamary et al., 2013, p. 11). 
The thing that each information system needs to provide is quality information support. That means that the information system user will receive accurate information at the right time and will be satisfied because he/she received the requested information. In that way, information support increases the quality in problem solving and decision making. The more satisfied the user is with information support, the more he/she will use it in his/her work.

This paper explains that the information support quality means that the information system is easy to use, has great reliability in work and information is easily accessible and adaptable to the needs of the user.

\section{INFORMATION QUALITY}

Quality information needs to enable easier accomplishment of user's business. Information quality has become a critical concern of organizations and an active area of Management Information Systems research (Lee et al., 2002, p. 133). Quality information is the desired output of each information system. "Information quality measures the output of information system and does not measure the quality of that system (DeLone \& McLean, 1992, p. 64).

Information quality provided by information system as an output can be measured in various ways and using various approaches. DeLone and McLean (2003) used the following characteristics which are required for the information to be of good quality: precise, timely, complete, relevant and coherent. Al-Mamary et al. (2013, p.12) outline the following desired features required for quality information: accurate, complete, brief, coherent, relevant, timely, sufficient amount, available and understandable.

The most important quality of information is for them to enhance the decision making performance, increase work efficiency and improve the quality of information system users. The mission of each piece of information is to contain all re- quired data relevant for problem solving, decision making and everyday business activities.

\section{INFORMATION SUPPORT IN DECISION MAKING}

Each user is required to receive timely and accurate information needed for the decision making process.

The basic information technology support is in decision making. Managing any type of organization includes decision making and resolution of daily as well as specific problems. Therefore, it is necessary to possess certain knowledge and information (Stanišić, 2014, p. 73). Information systems with their information support are needed for the user to obtain information required for decision making and problem solving. In order to increase efficiency in the decision making process, it is required to possess real information at the right time. Decision making is the process of problem identification and its resolution (Mašić et al., 2010, p. 195).

"Information system needs to be reliable, comprehensive and operational, established to enable simple data and information approach in a way to please the user needs and also needs to support the processes of rational strategic and operational decision making” (Imamović \& Redžić, 2012, p. 197).

Information systems assist managers in resolving two types of problems: optimizing the business process and process of manager information supply. The most important section of information system in decision making is to help the managers by using all relevant information.

\section{PERCEPTION OF INFORMATION SUPPORT USAGE}

Perception of information support usage is defined by Davis (1989, p. 320) as the degree of user's efficiency and validity to improve his/her business efficiency. It is related to the user's satisfaction with information support obtained in everyday business activities, decision making, problem solving, all of 
which they encounter at work. The perceived usage of information system cannot be seen as something that is used for decision making but rather to assist in user's everyday business. The definition was given by Mathwick et al. who define the perceived usage as the degree by which a person thinks that a certain system improves business conducting.

In order for the information system to improve the perceived usage of users, it is required to enable rapid decision making, increase work efficiency and problem solving, and improve productivity and performance of user information system. This could lead to the increased awareness of the usage of information systems, information support in everyday business. The perceived usage of users rises along with the increase of awareness.

Each information system needs to secure easier business activities for the users/clients. The better support, the higher the perception of its usage by the user. If the information system provides necessary information support to the user, he/she will be dissatisfied with the system and the perceived efficiency will reduce and its use will record a growing tendency in everyday business.

\section{SATISFACTION WITH INFORMATION SUPPORT}

Customer satisfaction refers to how satisfied a customer is with the supplied product/service (Eid, 2011, p. 88). When you mention the term "satisfaction with information support", it means positive experience with information system in the past. Primary satisfaction is created when all information for everyday business is obtained and easily accessible.

The user measures his/her satisfaction with the output data of information system, which is shown as information support. By using the output approach to the information system, Halawi et al. (2008, p. 126) define satisfaction with information system through user requests that are shown as the available information on information support.

If the user thinks that the information system is useful for providing information support, he/she will try to use it in all aspects of his/her work. But, otherwise, he/she will not use it even in the places where it is the most effective at work.

In order to increase user satisfaction, it is necessary to apply different enforcement strategies for the user to be actively involved in the creation of these systems. By doing so, the user will become more familiar with the entire process. If the user understands how the system functions and if he/ she knows how to use it, he/she will be meeting his/her needs better than the users who were not involved in the creation of such systems. This will greatly affect the loyalty and readiness to use such systems in future (Halilović, 2015, p. 71).

Doll et al. (1994, p. 461) state that the most important measuring tool of client satisfaction with information system is the information support to the end user, as well as information on user satisfaction.

\section{LOYALTY TOWARDS INFORMATION SUPPORT}

This paper assumes that the loyalty is the intention of continuous usage of certain information support. Customer loyalty is customer intention to reuse something based on his experience and expectancy in the past (Hadi et al., 2012). Of course, loyalty can also be defined in other ways. Oliver (1997, p. 392) views loyalty as deep dedication to the repeated purchase of the preferred product or service, despite the situational influences and marketing efforts of the opposition which have the potential to create the supplier change. In the environmental context, customer loyalty is measured based on the number of customers performing transactions (Kim et al., 2003).

When defining loyalty, it is necessary to include user perception. Based on that perception, the user satisfaction or dissatisfaction is created. In case of satisfaction, the loyalty is created whereas in case of dissatisfaction the user will use different methods in the future, which is not the case with 
physical products (Babić-Hodović \& Činjarević, 2009, p. 738). In order to increase loyalty of the information system user, the quality of the system itself needs to be improved and the user needs to be satisfied with that system. Without the satisfied user, there is no loyal user, and satisfaction is connected with quality.

\section{RESEARCH METHODOLOGY}

The basis of this research is the employer of Brcko District, Bosnia with access to one of information systems. Questionnaires are given to those users for the primary research to be conducted. The research itself was conducted in the following way:

- questionnaire formation,

- defining the main target,

- forwarding questionnaires,

- gathering completed questionnaires,

- processing research results,

- research result presentation.

The questionnaire comprises two parts: characteristics of examinees and claims connected to research varieties. For the purpose of questionnaire examination, the following characteristics have been considered: age, sex, workplace, school, work experience and weekly system usage. For variety questioning, Likert scale method with five intensity levels was used, with 1 meaning I disagree and 5 meaning I agree.

Two-approach level was used for conducting this research and included the following: sending the electronic version of the questionnaire to Brcko District, Bosnia and Herzegovina, Government employees and forwarding the paper version to the employees, which gave better effects. That is also confirmed by the research conducted by Kwak and Radler (2002), which shows that there is a smaller responsiveness rate with online research performed by the examinees.

Based on this research, 141 completed questionnaires were received. The return rate was $47 \%$ since the survey was forwarded to 300 users of information system. The user selection was conducted using the non-random sample method. "This sample is used with population for which we assume to be homogenous towards the observed characteristics" (Fazlović, 2013, p. 151). In this case, we had homogenous observed users and therefore, the non-random sample was used.

As regards the data analysis, statistical packets SPSS 20 and Stastica 12.5 were used. During the hypothesis analysis, inferential statistics was used for the importance level of 5 per cent or $\mathrm{p}<0,05$. For hypothesis connection, factor analysis was used, while Crombach alpha method was implemented for reliability examination.

\section{RESULTS}

The purpose of this research is to determine whether the varieties in the set exploration model are mutually connected. Table 1 shows the basic characteristics of examinees.

Based on all basic examinee characteristics, no specific differences could be observed between the selected groups. Accordingly, the results obtained can be accepted and marked as relevant.

Prior to examining the set hypotheses, it is necessary to inquire the collected data. The reliability of data received is measured on the basis of Crobach's alpha coefficient value. While performing the factor analysis, data reliability was inquired based on Kaiser-Meyer-Olkinov (KMO) and Bartlett tests. The mutual connection of varieties was measured by means of correlation analysis.

The task of Cronbach's alpha index is to examine the internal consistency of received data (Carlbring et al., 2007, p. 1427). Cronbach's alpha value is from theoretical zero to one. If the index value is close to zero, it can be said that data is unreliable. If the values are close to one, it can be said that data is very reliable (Kozarević \& Puška, 2015, p. 589).The value of this index needs to be higher than 0.75 for the data to be considered reliable.

Factor analysis is used herein to explore inter- 


\begin{tabular}{|c|c|c|c|}
\hline \multicolumn{2}{|c|}{ Examinee characteristics } & \multirow{2}{*}{$\begin{array}{c}\text { Frequency } \\
83 \\
\end{array}$} & \multirow{2}{*}{$\begin{array}{c}\text { Percentage } \\
58,87 \%\end{array}$} \\
\hline Sey & Male & & \\
\hline $\operatorname{sex}$ & Female & 58 & $41,13 \%$ \\
\hline \multirow{5}{*}{ Work place/position } & assistant; clerk & 45 & $32,14 \%$ \\
\hline & expert assistant & 21 & $15,00 \%$ \\
\hline & senior expert assistant & 33 & $23,57 \%$ \\
\hline & consultant & 8 & $5,71 \%$ \\
\hline & assistant; manager & 33 & $23,57 \%$ \\
\hline \multirow{4}{*}{ Examinee age } & do 30 years & 23 & $16,31 \%$ \\
\hline & $30-40$ years & 48 & $34,04 \%$ \\
\hline & $41-50$ years & 33 & $23,40 \%$ \\
\hline & 51 years and more & 37 & $26,24 \%$ \\
\hline \multirow{3}{*}{ School qualification } & Secondary & 33 & $25,58 \%$ \\
\hline & Academy & 77 & $59,69 \%$ \\
\hline & MA degree; doctorate & 19 & $14,73 \%$ \\
\hline \multirow{5}{*}{ Work experience } & up to 5 years & 31 & $23,31 \%$ \\
\hline & 6-10 years & 34 & $25,56 \%$ \\
\hline & $11-15$ years & 24 & $18,05 \%$ \\
\hline & $16-20$ years & 23 & $17,29 \%$ \\
\hline & 20 years and more & 21 & $15,79 \%$ \\
\hline \multirow{5}{*}{ Weekly use of the system } & up to 5 hours & 20 & $15,27 \%$ \\
\hline & 6-10 hours & 25 & $19,08 \%$ \\
\hline & 11-15 hours & 31 & $23,66 \%$ \\
\hline & 16-20 hours & 28 & $21,37 \%$ \\
\hline & over 20 hours & 27 & $20,61 \%$ \\
\hline
\end{tabular}

Table 1. Basic examinee characteristics

nal connection of claims inside one variety. The main component analysis and varimax rotation with Kasiser normalization were used during the factor analysis. In order to examine factor analysis data reliability, Kaiser-Meyer-Olkin (KMO) indicator of sample adequacy is used as well as Bartlet spherical test. KMO indicator varies from zero to 1 . If the result is smaller than 0.6 , correlation matrix is not suitable for this analysis. Bartlett's test finds the significance value to be smaller than 0.05 ( $<<0.05)$ desirable (Puška et al., 2015, p. 108).

The results of internal connection of claims within research varieties indicate strong correlation between them. The smallest value of factor analysis was established with the variety of information support usage where the numbers varied between 0.837 and 0.935 .
Other index values obtained from this analysis were bigger and were close to 1 , which represents an excellent value for internal connection. As can be seen from the factor analysis, all varieties have one factor. Therefore, it can be said that one-factor analysis of internal connection of research was conducted. All values are bigger than 0.6 , and thus it can be said that the correlation matrix is needed for the analysis. The Bartlett's test value is smaller than 0.05 for all factor analyses.

The value of this test for all analyses is $\mathrm{p}<0.000$. Based on this research, it can be concluded that there is not even the slightest possibility for statistical error occurrence since the zero has three decimals.

Based on the above-stated, it can be concluded that the collected exploration data is mutually internally coherent and that there is only one factor that explains the research varieties. 


\begin{tabular}{|c|c|c|c|}
\hline Mark & Claim & $\begin{array}{l}\text { Factor con- } \\
\text { nection }\end{array}$ & $\begin{array}{l}\text { Data reli- } \\
\text { ability }\end{array}$ \\
\hline \multicolumn{4}{|c|}{ Quality of information support system } \\
\hline KSIP 01 & Simple for use & 0,970 & \multirow{4}{*}{0,978} \\
\hline KSIP 02 & Has great confidence at work & 0,977 & \\
\hline KSIP 03 & Information is easy to get & 0,971 & \\
\hline KSIP 04 & Easily adapts to user's needs & 0,955 & \\
\hline \multicolumn{4}{|c|}{$\mathrm{KMO}=0,849 ;$ Bartlet test $\mathrm{p}<0,000$; Explained varieties $93,75 \%$} \\
\hline \multicolumn{4}{|c|}{ Quality of information obtained through information support } \\
\hline KIIP 01 & It is possible to get reliable information & 0,961 & \\
\hline KIIP 02 & It is possible to get all significant information & 0,958 & \\
\hline KIIP 03 & It is possible to get accurate information & 0,975 & 0,983 \\
\hline KIIP 04 & It is possible to get clear information & 0,974 & \\
\hline KIIP 05 & It is possible to get coherent information & 0,970 & \\
\hline \multicolumn{4}{|c|}{$\mathrm{KMO}=0,862 ;$ Bartlet test $\mathrm{p}<0,000 ;$ Explained varieties 93,63\% } \\
\hline \multicolumn{4}{|c|}{ Information support with decision making } \\
\hline IPDO 01 & Information support helps me in daily decision making & 0,954 & \\
\hline IPDO 02 & Information support makes everyday work much easier & 0,970 & \\
\hline IPDO 03 & $\begin{array}{l}\text { Information required for decision making is obtained through } \\
\text { information support }\end{array}$ & 0,946 & 0,979 \\
\hline IPDO 04 & By using information support, work efficiency is increased & 0,970 & \\
\hline IPDO 05 & By using information support, work performance is increased & 0,961 & \\
\hline
\end{tabular}

\begin{tabular}{|c|c|c|c|}
\hline \multicolumn{4}{|c|}{$\mathrm{KMO}=0,855 ;$ Bartlet test $\mathrm{p}<0,000$; Explained varieties $92,21 \%$} \\
\hline \multicolumn{4}{|c|}{ Perceived use of information support } \\
\hline PKIP 01 & Information support is exceptional & 0,978 & \multirow{4}{*}{0,976} \\
\hline PKIP 02 & It fulfills user's needs & 0,976 & \\
\hline PKIP 03 & Functional possibilities of information support are great & 0,967 & \\
\hline PKIP 04 & Information support is very useful for my work & 0,941 & \\
\hline \multicolumn{4}{|c|}{$\mathrm{KMO}=0,866 ;$ Bartlet test $\mathrm{p}<0,000 ;$ Explained varieties 93,28\% } \\
\hline \multicolumn{4}{|c|}{ Satisfacion with information support } \\
\hline ZIPS 01 & I am satisfied with the overall information support & 0,974 & \multirow{4}{*}{0,984} \\
\hline ZIPS 02 & Information support satisfies all my needs and expectations & 0,977 & \\
\hline ZIPS 03 & Information support is efficient and effective & 0,983 & \\
\hline ZIPS 04 & Information support performance is exceptional & 0,975 & \\
\hline \multicolumn{4}{|c|}{$\mathrm{KMO}=0,856$; Bartlet test $\mathrm{p}<0,000 ;$ Explained varieties $95,50 \%$} \\
\hline \multicolumn{4}{|c|}{ Loyalty of information support usage } \\
\hline LKIN 01 & If I was offerred other information support, I would not accept it & 0,880 & \multirow{4}{*}{0,916} \\
\hline LKIN 02 & I intend to continuously use this support & 0,935 & \\
\hline LKIN 03 & I try to include information support in my activity & 0,925 & \\
\hline LKIN 04 & I would gladly use newer systems of information support & 0,837 & \\
\hline
\end{tabular}

\section{Table 2. Examination of connection and data reliability}

In addition, the values of factor analysis are high, and none of the claims is rejected from further analysis. The result value obtained through Cronbach's alpha is shown as being bigger than 0.91 and closer to 1 . Thus, it can be concluded that all collected data is relevant and reliable.
This section will explore the research set hypotheses using the multi-variation regression analysis. The aim of multiple regressions is the inclusion of multiple factors in the analysis both individually and separately, where the estimation of factor influence from independent to dependent variable is 
done. Multiple regressions are quite flexible and can be suitable when analyzing the dependent variety in relation to more independent varieties (Božić, et al. 2013, p. 43).

The thing that needs to be mentioned with multiple regression is that this analysis provides evaluation of all research factors as well as individual factor influence of independent variety on the dependent one where the F-test value and the relevance of this test is given.

Multiple regressions make it possible to make an equation of independent factor influence on dependent ones, where the independent factor value is determined using " $\mathrm{B}$ " coefficient, which represents the items for minimizing the mathematical method mistakes. The implementation of multiple regressions will be done using the programming tool Statistica 12.5.

As previously mentioned, the research model in the first hypothesis uses information support quality as an independent variety, whereas information support is used as a dependent variety in the decision making process. The mission of this hypothesis is to examine the influence of information support quality on the user's decision making. The total model assessment is being used for examining the first hypothesis.

The results of multiple regression show that there is a slight and almost significant link between the observed varieties of research and multiple correlation coefficient $(\mathrm{R})$ which is 0.7822 , whereas the determination coefficient value is $\mathrm{R} 2=0.6118$. This coefficient shows the proportion of criterion that can be explained on the basis of variety aggregate. Based on the value of determination coefficient, it can be said that with this model of multiple regression 61.18 per cent of dependent varieties are explained based on the variety aggregate. The value of the standard error rate is 0.70639 , which is considered to be relatively small. With this model, the F-test value is 48.468 , which is bigger than the table value. Therefore, it can be said that this research hypothesis is accepted. This also proves the p-value or the level of model significance. Based on these tests, it can be concluded that information support quality influences the decision making in everyday life of users, which proves the first hypothesis.

After the total aggregate value of the model was explained, the results of individual indicators of independent variety on dependent variety factors shall be evaluated. The multiple regression results reveal that only one indicator plays a significant role in dependent variety explanation, thus indicating that information support easily adapts to the user's requests where the T-test value for this indicator is 3.5690 , while the significance level is 0.0005 .

Coefficients of regression in this model are presented as " $B$ " values. Based on that, it can be said that the value of regression coefficient for the mentioned indicator is 0.5398 . This value is positive and in line with regression direction. The thing that is still valuable is constant value and its importance level is 0.0040 , while for the remaining indicator values this level is significantly bigger. It is also important to mention the KSIP 02 indicator. The quality of information support has more reliability in business where regression coefficient is negative and is -0.0317 , while the significance level value is bigger and is 0.8930 .

The results of multiple regression usage for the second established hypothesis show that there is a large connection between the observed varieties. Information quality was used as an independent variety and information support as dependent one in decision making. The value of multiple correlation analysis is 0.7680 while the determination coefficient is valued at 0.5898 based on which it can be said that with independent variety, 58.98 per cent of dependent variety was explained. The standard error estimate rate is labeled as 0.73256 , which is slightly less than the previous multiple models.

The T-test value in this case is valued at 35.365 , which is bigger than the table value. The T-test value is used for hypothesis verification. The second backing hypothesis is accepted. It states that the quality of information influences decision making 
in everyday user's business activities. Besides that, the p-value result is smaller than 0.05 , which also proves the second research hypothesis.

By observing individual claims and their influence on the independent variety, it can be noticed that none of the stated claims individually is significantly important i.e. it does not influence the dependent variety. Two claims have negative values of regression, the KIIP 01 and KIIP 03, whose T-test values are -0.7476 and -0.5766 , respectively. These two claims have the biggest level of significance ranging from 0.4561 and 0.5652 . Other indicators have positive regression coefficient value, so the smallest significance level is at KIIP 02 claim and is 0.0855 , which is close to the border value of 0.05 . However, it cannot be said that this claim has a significant influence on the dependent variety of information support in decision making.

Total model assessment

$\mathrm{R}=0,7822 ; \mathrm{R}^{2}=0,6118 ;$ Addapted $\mathrm{R}^{2}=0,5992 ; \mathrm{F}($ test $)=48,468 ; \mathrm{p}<0,0000 ;$ standard error estimate rate: 0,70639

\begin{tabular}{ccccc}
\hline \multirow{2}{*}{ Model } & \multicolumn{2}{c}{ Ungraded coefficients } & \multirow{2}{*}{ T-test } & \multirow{2}{*}{ Significance } \\
\cline { 2 - 3 } & $\mathrm{B}$ & Standard Error & & \\
\hline (Constant) & 0,7002 & 0,2388 & 2,9326 & 0,0040 \\
\hline KSIP 01 & 0,2546 & 0,2167 & 1,1747 & 0,2424 \\
\hline KSIP 02 & $-0,0317$ & 0,2354 & $-0,1348$ & 0,8930 \\
\hline KSIP 03 & 0,0599 & 0,1848 & 0,3240 & 0,7465 \\
\hline KSIP 04 & 0,5398 & 0,1512 & 3,5690 & 0,0005 \\
\hline
\end{tabular}

Table 3. Results of multiple regression for hypothesis 1 examination

Total model assessment

$\mathrm{R}=0,7680 ; \mathrm{R}^{2}=0,5898 ;$ Adapted $\mathrm{R}^{2}=0,5731 ; \mathrm{F}($ test $)=35,365 ; \mathrm{p}<0,0000 ;$ standard error estimate rate: 0,73256

\begin{tabular}{ccccc}
\hline \multirow{2}{*}{ Model } & \multicolumn{2}{c}{ Unstandard coefficients } & \multirow{2}{*}{ T-test } & \multirow{2}{*}{ Significance } \\
\cline { 2 - 3 } & $\mathrm{B}$ & Standard error & & 0,0049 \\
\hline (Constant) & 0,7144 & 0,2493 & 2,8654 & 0,4561 \\
\hline KIIP 01 & $-0,1556$ & 0,2081 & $-0,7476$ & 0,0855 \\
\hline KIIP 02 & 0,3510 & 0,2025 & 1,7337 & 0,5652 \\
\hline KIIP 03 & $-0,1347$ & 0,2336 & $-0,5766$ & 0,1196 \\
\hline KIIP 04 & 0,3975 & 0,2536 & 1,5674 & 0,1872 \\
\hline KIIP 05 & 0,3409 & 0,2570 & 1,3264 & 0 \\
\hline
\end{tabular}

Table 4. Results of multiple regressions for hypothesis 2 examination

Total model assessment

\begin{tabular}{|c|c|c|c|c|}
\hline \multirow{2}{*}{ Model } & \multicolumn{2}{|c|}{ Unstandard coefficients } & \multirow{2}{*}{ T-test } & \multirow{2}{*}{ Significance } \\
\hline & $\mathrm{B}$ & Standard error & & \\
\hline (Constant) & 0,8518 & 0,2466 & 3,4541 & 0,0008 \\
\hline IPDO 01 & 0,3431 & 0,1951 & 1,7584 & 0,0812 \\
\hline IPDO 02 & 0,0088 & 0,2310 & 0,0379 & 0,9698 \\
\hline IPDO 03 & $-0,0739$ & 0,1550 & $-0,4765$ & 0,6346 \\
\hline IPDO 04 & 0,1384 & 0,2503 & 0,5529 & 0,5813 \\
\hline IPDO 05 & 0,3584 & 0,2204 & 1,6266 & 0,1064 \\
\hline
\end{tabular}

Table 5. Results of multiple regressions for hypothesis 3 examination 
The results of multiple regression implementations in hypothesis 3 show that the two varieties, dependent and independent one, are connected and that the value of multiple correlations is 0.7556 , which is slightly less than with previously established multiple regression models. This model, with the help of independent variety, explained 57.10 per cent of dependent variety, which shows the value of determination coefficient. The standard error estimate rate for this model is 0.71525 , which is almost equal to the values in previous models. As with the previous model, the established hypothesis is accepted because the F-test value is bigger than the table value while the $\mathrm{p}$-value is smaller than 0.05 , which confirms that information support in decision making influences the user's perceived usage of this support.

As for the individual influence of indicators of information support in decision making, we can say that there is no significant influence of individual indicators on the variety of the perceived usage of information support. The only important value is the constant value. The regression coefficient is 0.8518 while the significance value is 0.0008 . As for the indicators, we can see that IPDO 02 (Information support facilitates my everyday work) indicator does not influence the dependent variety and its regression value is 0.0088 , while the significance value is at 0.9698 . It has already been emphasized that the closer the p-value is to zero, the bigger the influence, and vice versa. For the value of 1 we can say that there is no influence. Since this value is close to 1 , we can say that there is no influence of this indicator on dependent variety.

The value of correlation coefficient is negative for IPDO 03 indicator and is -0.0739 , while the significance value for this indicator is 0.6346 . The remaining indicators have positive value with regressive function.

The results of multiple regressions showed that these two varieties are nicely connected and that the value of multiple correlation coefficients is 0.7755 . This model of multiple regressions encompasses 60.14 per cent of influence that independent varie- ty has on the dependent one which shows the value of determination coefficient. As for the statistical error, it is less than with previous models. The Ftest value, which is 36.509 , and p-value, which is 0.000 , shows a significant statistical influence of independent value on the dependent one with this model of multiple regressions.

Based on these results, we can conclude that information support in decision making has influence on user's satisfaction with this support. That is why the fourth hypothesis has been accepted.

There is no significant influence of information support indicators in decision making on the variety of satisfaction with information support. The multiple regression results show that there is only a great level of significance with the constant value in regression function, while other indicators do not have the importance level required to show that there is a significant statistical importance of the influence of these indicators on the dependent variety. The IPDO 04 variety has the smallest influence, with the value of 0.9656 . This is the only indicator with a negative regression coefficient. With the remaining regression coefficients, there is a positive influence on the dependent variety.

During the research of influence that the perceived usage of information support has on information system loyalty, the results of multiple regressions were obtained, and they reveal a slight connection between these varieties.

The value of multiple correlation analysis is the smallest in regards to other models of multiple regressions and is 0.4733 . This analysis encompassed only 22.4 per cent of influence that independent variety has on the dependent one, which is shown by the determination coefficient. The standard error estimate rate is the highest of all other models of multiple regressions and is 1.2328 . However, besides all other F-test (98.8768) and p-values (0.000), the fifth hypothesis is accepted and it shows that there is a significant influence of the perceived usage on loyalty in usage of information support system. 
During the research of individual influence of independent variety on dependent one, the results obtained show that only the constant has the sufficient value of significance for this statistical index to be considered important with p-value being 0.0007. It is important to state that PKIP 04 indicator has the biggest influence on the dependent variety and its significance level is 0.0564 . Meanwhile, this level is higher than the set level with used inferential statistics. This indicator also has the highest regression coefficient in regards to other indicators, which is 0.4385 . PKIP 02 indicator has the smallest influence with $\mathrm{p}$-value being the highest (0.9939), which is very close to 1 , meaning there is not even the slightest significant statistical influence of this indicator on the dependent variety.

The results of multiple regression show that the value of multiple correlation for this model of multiple regression is 0.5840 , and that there is a significant connection of research varieties. This model encompassed 31.98 per cent of influence

Total model assessment

\begin{tabular}{|c|c|c|c|c|}
\hline \multicolumn{5}{|c|}{$\mathrm{R}=0,7755 ; \mathrm{R}^{2}=0,6014 ;$ Adapted $\mathrm{R}^{2}=0,5849 ; \mathrm{F}($ test $)=36,509 ; \mathrm{p}<0,0000 ;$ standard error estimate rate: 0,69544} \\
\hline \multirow{2}{*}{ Model } & \multicolumn{2}{|c|}{ Unstandard coefficients } & \multirow{2}{*}{ T-test } & \multirow{2}{*}{ Significance } \\
\hline & $\mathrm{B}$ & Standard error & & \\
\hline (Constant) & 0,8571 & 0,2406 & 3,5627 & 0,0005 \\
\hline IPDO 01 & 0,3104 & 0,1864 & 1,6655 & 0,0984 \\
\hline IPDO 02 & 0,1477 & 0,2251 & 0,6559 & 0,5132 \\
\hline IPDO 03 & 0,0456 & 0,1578 & 0,2889 & 0,7732 \\
\hline IPDO 04 & $-0,0128$ & 0,2962 & $-0,0432$ & 0,9656 \\
\hline IPDO 05 & 0,3078 & 0,2851 & 1,0798 & 0,2824 \\
\hline
\end{tabular}

Table 6. Results of multiple regressions for hypothesis 4 examination

Total model assessment

$\mathrm{R}=0,4733 ; \mathrm{R}^{2}=0,2240 ;$ Adapted $\mathrm{R}^{2}=0,1987 ; \mathrm{F}$ (test) $=8,8758 ; \mathrm{p}<0,0000$; standard error estimate rate: 1,2328

\begin{tabular}{ccccc}
\hline \multirow{2}{*}{ Model } & \multicolumn{2}{c}{ Unstandard coefficients } & \multirow{2}{*}{ T-test } & \multirow{2}{*}{ Significance } \\
\cline { 2 - 3 } & $\mathrm{B}$ & Standard error & & \\
\hline (Constant) & 1,4576 & 0,4215 & 3,4582 & 0,0007 \\
\hline PKIP 01 & 0,2411 & 0,4201 & 0,5739 & 0,5671 \\
\hline PKIP 02 & 0,0031 & 0,3998 & 0,0076 & 0,9939 \\
\hline PKIP 03 & $-0,0740$ & 0,3149 & $-0,2350$ & 0,8145 \\
\hline PKIP 04 & 0,4385 & 0,2277 & 1,9258 & 0,0564 \\
\hline
\end{tabular}

Table 7. Results of multiple regressions for hypothesis 5 examination

Total model assessment

$\mathrm{R}=0,5840 ; \mathrm{R}^{2}=0,3411 ;$ Adapted $\mathrm{R}^{2}=0,3198 ; \mathrm{F}($ test $)=16,047 ; \mathrm{p}<0,0000$; standard error estimate rate: 1,1234

\begin{tabular}{lcccc}
\multirow{2}{*}{ Model } & \multicolumn{2}{c}{ Unstandard coefficients } & \multirow{2}{*}{ T-test } & Significance \\
\cline { 2 - 3 } & $\mathrm{B}$ & Standard error & & 0,0028 \\
\hline Constant) & 1,1663 & 0,3831 & 3,0443 & 0,3530 \\
\hline ZIPS 01 & $-0,3019$ & 0,3239 & $-0,9322$ & 0,0127 \\
\hline ZIPS 02 & 0,8779 & 0,3473 & 2,5279 & 0,1446 \\
\hline ZIPS 03 & $-0,6010$ & 0,4094 & $-1,4681$ & 0,0413 \\
\hline ZIPS 04 & 0,7259 & 0,3520 & 2,0622 &
\end{tabular}

Table 8. Results of multiple regressions for hypothesis 6 examination 
that the independent variety has on the dependent one, which shows the value of determination coefficient. The value of standard error estimate rate is less than with the previous model of multiple regressions, but higher than the first four models and is 1.1234. With previous models, the sixth hypothesis can be accepted based on the F-test value (16.047) and p-value (0.0000), which represents significance level.

The partial analysis of indicator influence shows that there is a significant influence with two indicators. Those indicators are ZIPS 02 and ZIPS 04 and their p-values are 0.0127 and 0.0413 , respectively. It can be seen that ZIPS 02 has the higher T-test (2.5279) value than ZIPS 04 indicator (2.0622). Based on that and the p-value, it is possible to determine that ZIPS 02 has the higher influence in relation to ZIPS 04 on depending variety of this model of multiple regressions. It is also important to mention that the significant value of the constant is 0.0028 . The remaining two indicators have a negative value of regression coefficient and adverse effects on the regression function.

\section{CONCLUSIONS}

The use of information systems is important for the efficient decision making process. The application of information systems results in providing information support to the user. Because of that, this paper completed system modeling through information support to the user. When forming the model, considerable attention was devoted to how information support influences decision making through quality. All this influences the perceived usage, satisfaction and user loyalty.

The main aim of this model was to show the impact of information system.

The information system itself, through information support, provides all required information for daily business activities and decision making. The model was projected into three phases: the first phase shows the influence that the quality of information support has on the decision making process itself and conducting of daily business activities. The second phase shows the influence of information support on decision making on the perceived usage and user's satisfaction with information support. The third phase examines the influence that the perceived usage and information support satisfaction has on user's loyalty to this support.

The research was conducted in Brcko District, Bosnia and Herzegovina, among government employees. Accordingly, 141 completed questionnaires were collected. All categories of information system user's characteristics have been included. Upon data collection, the relevance and research varieties connection was performed using factor analysis and Cronbach's alpha coefficient. The results of this method's show that the collected information is reliable and coherent and suitable for the application of multiple regression method.

To that end, six hypotheses were established and verified by means of multiple regression methods. The results show that all hypotheses have been accepted. The detailed analysis of the F-test shows that the quality of information support had the biggest impact on the decision making process. The test value was 48.468 . The smallest influence was with the perceived information support usage on user loyalty, with value being 8.8758 . The multiple regression results showed that the set hypotheses are accepted as well as the research model.

Based on the aforementioned, the future research should consider using this model in other spheres and sections. Moreover, it is also needed to examine mutual influence of certain categories used herein, which has not been encompassed by the present research.

It is also of vital importance to compare this model with other models and identify its advantages and disadvantages.

\section{REFERENCES}

Al-Mamary, Y.H., Shamsuddin, A., \& Aziati, N. (2013). The Impact of Management Information Systems Adoption in Managerial Decision Making: A Review. The International Scientific Journal of Management Information Systems, 8(4), 10-17. 
Babić-Hodović, V., \& Činjarević, M. (2009). Uticaj percepcije kvaliteta usluga edukacije na lojalnost klijenata. VI Naučno-stručni skup sa međunarodnim učešćem KVALITET 2009, (pp. 737-744). Retrieved April 6, 2016, from http://www.quality.unze.ba/ zbornici/QUALITY\%202009/123-Q09-024.pdf. In Bosnian.

Božić, B., Milićević, D., Pejić, M., \& Marošan, S. (2013). The use of multiple linear regression in property valuation. Geonauka, 1(1), 41-45.

Carlbring, P., Brunt, S., Bohman, S., Austin, D., Richards, J., Öst, L.G., \& Andersson, G. (2007). Internet vs. paper and pencil administration of questionnaires commonly used in panic/agoraphobia research. Computers in Human Behavior, 23(3), 14211434. doi:10.1016/j.chb.2005.05.002

Davis, F.D. (1989). Perceived usefulness, perceived ease of use, and user acceptance of information technology. MIS Quarterly, 13(3), 319-340. doi:10.2307/249008

DeLone, W.H., \& McLean, E.R. (2003). The DeLone and McLean Model of Information Systems Success: A Ten-Year Update. Journal of Management Information Systems, 19(4), 9-30.

DeLone, W.H., \& McLean, E.R. (1992). Information Systems Success: The Quest for the Dependent Variable. Information Systems Research, 3(1), 60-95.

Doll, W.J., Xia, W., \& Torkzadeh, G. (1994). A confirmatory factor analysis of the end-user computing satisfaction instrument. MIS Quarterly, 18(4), 453461. doi:10.2307/249524

Fazlović, S. (2013). Primijenjena statistika. Tuzla: Offset. In Bosnian.

Hadi, S.P., Purwanto, E., \& Khrisna, D. (2012). Antecedents of trust and its impact on loyalty: An empirical study on e-commerce's customer in Surabaya. International Journal of Information and Communication Technology Research, 2(2), 112-128.

Halawi, A., Mccarthy, P.L., \& Aronson, E.J. (2008). An Empirical Investigation of Knowledge Management System's Success. Journal of Computer Information Systems, 48(2), 121-135. doi:10.1080/08874417.2008.11646014

Halilović, S. (2015). Utjecaj kvalitete usluge na zadovoljstvo i namjeru nastavka korištenja informacijskih sustava. Tržište, 27(1), 57-74. In Croatian.

Imamović, A., \& Redžić, S. (2012). Razvoj ekološkog informacionog sistema u funkciji održivog upravljanja vodenim ekosistemima. Međunarodni naučni skup Struktura i dinamika ekosistema Dinarida - stanje, mogućnosti i perspektive: posvećen životu i naučnom djelu profesora emeritusa dr. Muse Dizdarevića: zbornik radova (pp. 185-199). Sarajevo: Akademija nauka i umjetnosti Bosne i Hercegovine. In Bosnian.

Kim, D.J., Ferrin, D.L., \& Rao, H.R. (2003). Antecedents of consumer trust in B-to-C electronic commerce. Americas Conference on Information Systems, Paper 21. Retrieved April 6, 2016, from http://aisel. aisnet.org/amcis2003/21

Kozarević, S., \& Puška, A. (2015). Povezanost primjene lanca opskrbe, partnerskih odnosa i konkurentnosti. Ekonomska misao i praksa, 10(2), 579-596. In Croatian.

Kwak, N., \& Radler, B. (2002). A Comparison Between Mail and Web Surveys: Response Pattern, Respondent Profile, and Data Quality. Journal of Official Statistics, 18(2), 257-273.

Lee, Y.W., Strong, D.M., Kahn, B.K., \& Wang, R.Y. (2002). AIMQ: a methodology for information quality assessment. Information \& Management, 40(2), 133-146. doi:10.1016/S0378-7206(02)00043-5

Mahmutović, H., Kulović, Dž., Jurešić, S., \& Šabić, A. (2012). Konvergencija rasta malih i srednjih preduzeća u $\mathrm{BiH}$ i razine primjene informacijskih sistema za podršku u procesu odlučivanja. Tranzicija, 14(30), 39-53. In Bosnian.

Marković Blagojević, M., Mikarić, B., \& Trajković, D. (2014). Kompjuterski sistemi kao podrška odlučivanju. Trendovi u poslovanju, 2(4), 33-42. In Serbian.

Mašić, B., Đorđević-Boljanović, J., Babić, L., Dobrijević, G., \& Veselinović, S. (2010). Menadžment: principi, koncepti i procesi. Beograd: Univerzitet Singidunum. In Serbian.

Mathwick, C., Malhotra, N.K., \& Rigdon, E. (2002). The effect of dynamic retail experiences on experiential perceptions of value: an Internet and catalog comparison. Journal of Retailing, 78(1), 51-60. doi:10.1016/S0022-4359(01)00066-5

Mustafa Eid, I. (2011). Determinants of e-commerce customer satisfaction, trust, and loyalty in Saudi Arabia. Journal of Electronic Commerce Research, 12(1), 78-93.

Oliver, R.L. (1997). Satisfaction: A Behavioral Perspective on the Consumer. Hoboken: Taylor and Francis.

Petter, S., DeLone, W., \& McLean, E. (2008). Measuring information systems success: models, dimensions, measures, and interrelationships. European Journal of Information Systems, 17(3), 236-263. doi:10.1057/ ejis.2008.15

Puška, A., Maksimović, A., \& Fazlić, S. (2015). Utjecaj kvalitete na zadovoljstvo i lojalnost studenata. Poslovna izvrsnost, 9(2), 101-119. In Croatian. 
Stanišić, S. (2014). Važnost primjene finansijskog izvještavanja za razvoj korporativnog upravljanja. Zbornik radova: Međunarodna naučna konferencija Univerziteta Singidunum Finansijsko izveštavanje u funkciji korporativnog upravljanja, Beograd, 5. decembar 2014 (pp. 73-75). doi:10.15308/ finiz-2014-73-75. In Serbian.

\section{MODEL INFORMACIONIH SISTEMA ZA PODRŠKU ODLUČIVANJU I NJEGOV UTICAJ NA IZGRADNJU ZADOVOLJSTVA, LOJALNOSTI I VREDNOSTI ZA KORISNIKE}

\section{Rezime:}

U savremenom dobu, informacioni sistemi predstavljaju važan činilac za uspešno poslovanje bilo koje organizacije. Jedna od ključnih uloga informacionih sistema jeste informaciona podrška. $U$ radu se prikazuje model informacionih sistema za podršku u procesu odlučivanja i rezultati ankete o uticaju ovog modela. Istraživanje je sprovedeno u tri faze i obuhvatilo je zaposlene u Vladi Brčko distrikta.

Prva faza ispituje uticaj kvaliteta informacione podrške i informacija na informacionu podršku prilikom donošenja odluka. Druga faza ispituje uticaj informacionih sistema za podršku prilikom donošenja odluke o dostupnosti i zadovoljstvu korisnika pruženom podrškom. Treća faza ispituje uticaj percipirane vrednosti i zadovoljstva pruženom informacionom podrškom na lojalnost korisnika sistema. Ovaj model prikazan je pomoću šest hipoteza, koje su dokazane korišćenjem višestruke regresione analize.

Posmatrani model pokazuje da je kvalitet informacionih sistema i informacija od presudnog značaja prilikom donošenja odluka. Percipirana korisnost i zadovoljstvo korisnika veoma su važni za kontinuiranu upotrebu informacionih sistema za podršku u procesu odlučivanja. Prikazani model je univerzalan i uz sitne izmene, može se primeniti u bilo kojoj sferi života gde se meri zadovoljstvo klijenata i korisnika usluga.

\section{Ključne reči:}

informacioni sistem, informaciona podrška, model informacionih sistema za podršku odlučivanju, zadovoljstvo, lojalnost. 